\title{
Report on International Roundtable Meeting on Collection Security held at the British Library
}

\author{
Andy Stephens \\ Board Secretary and Head of International Engagement, \\ The British Library, 96 Euston Road, London NW1 2DB, UK, \\ andy.stephens@bl.uk \\ Helen Shenton \\ Head of Collection Care, The British Library, \\ 96 Euston Road, London NW1 2DB, UK, \\ Helen.shenton@bl.uk
}

\begin{abstract}
Anonymised report on some of the issues raised at an international roundtable on collection security of thirteen major research libraries and national libraries from Europe and North America. Recurring themes of case studies included: 1) perpetrator profiling; 2) relations with the criminal justice system; 3) systems; 4) looking out; 5) aftermath.
\end{abstract}

Key Words: Collection security; international roundtable; research libraries

In May 2008, following the LIBER Collection Security Conference at the British Library, a small International Roundtable of thirteen major research libraries and national libraries from Europe and North America was convened by the British Library to discuss issues of collection security.

The aims of this invitee-only, one-day meeting were for the libraries to share intelligence and experience in a secure and confidential environment, and 
to agree how to collaborate on collection security matters in the future. A number of recurring themes emerged from the institutional case studies and a number of key actions were agreed. The meeting was chaired by Ronald Milne, the British Library's Director of Scholarship \& Collections.

Participants agreed that the Roundtable event had been a most useful forum for the exchange of views and that it had provided an effective basis for future collaboration. Whilst there was clearly an appropriate balance to be struck between confidentiality and publicity, the participants agreed that an anonymised account of the issues raised would be of benefit to a wider audience of libraries.

\section{Recurring Themes}

During the morning session, each participating institution gave brief reports on recent collection security incidents and lessons learned. A number of recurring themes emerged from these institutional case studies. They have been distilled and are set out below under five categories.

\section{The Perpetrator}

A number of the participants focused on the motivation of the individuals responsible for thefts from libraries and the need for a corpus of data to enable possible perpetrator profiling. The ethics and practicalities of profiling were discussed. Of great concern was the threat from inside posed by those with privileged access to institutional collections. Discussion focused on whether there was a common profile of these individuals, how such a profile, or profiles, might be characterised and the tell-tale signs that would indicate that an individual might betray the institution's trust.

\section{The Theft: Relations with the Criminal Justice System}

The reports revealed some divergence of view between those institutions which considered that thefts should be reported to the police authorities at the earliest opportunity and those which considered that all available evidence needed to be amassed prior to reporting and that the institutions themselves 
were better able to conduct the investigations. It was also noted that there were systemic issues relating to identifying a malefactor and providing evidence of a theft as opposed to identifying whether an item was missing or mislaid. It was clear, though, that there was a need to maintain high momentum with investigations that they should be pursued with vigour and determination, and led at senior level, with a single point of responsibility.

Participants identified a number of areas where, in this context, the aims, objectives and priorities of the institutions on the one hand and the priorities of the criminal justice system and police investigations on the other were not fully aligned. It was also noted that the principal objective of the police and prosecuting authorities, i.e. to secure a conviction, was not necessarily always completely compatible with one of the principal objectives of the institution, namely to recover its collection items. Participants also considered that severity of sentencing in respect of theft of heritage material needed to reflect more adequately the value and significance of the items in question. The victim impact statements submitted by a number of institutions at the $\mathrm{E}$. Forbes Smiley III trial — which are in the public domain — contain very good material which lays out the cultural significance of collection material and the impact of the loss of individual items on whole collections. ${ }^{1}$

\section{Systems}

Participants highlighted the particular vulnerability of the small percentage of items for which there is no inventory listing. It was noted that sometimes the identification of collection losses might only occur when collection items were subsequently consulted by readers or curators, rather than as a result of systematic checking within an issue or auditing system. This also had implications for record retention periods.

Matters related to CCTV, workflow controls, access controls, inventory and stock-taking audits were discussed, together with, and in the context of, the balance of funding priorities. Participants noted that there was a potential tension between the recent trend towards broadening access, the adoption of a more welcoming culture, and the removal of barriers to access on the one hand and the need for increased collection security on the other. Similar cultural issues relating to employee trust were raised by the imposition of tighter controls on staff access. 


\section{Looking out}

Participants emphasised the importance of maintaining a close awareness of changing trends and values in the antiquarian and general markets, with a view to keeping up-to-date the institution's risk assessment of the vulnerability to theft of certain categories of material. Close relations with the antiquarian and second-hand trade are nurtured with a view to sharing intelligence and collaboration; participants considered that the importance of good relations with the antiquarian and second-hand trade could not be overstated. Participants also strongly underlined the value of communication, collaboration and the sharing of intelligence and good practice among institutions in networks and on email lists. This had been particularly important in recent cases.

\section{Aftermath}

The recovery of stolen items was regarded as an issue. Producing evidence of institutional ownership and the recovery of stolen items across national borders and jurisdictions could present problems. Participants noted that certain preventative and investigatory measures raised ethical issues.

Participants recognised that there was a number of significant questions relating to the publicity given to collection thefts and the conviction of perpetrators. The reputational risk associated with disclosure had to be balanced against the substantive benefits of sharing intelligence and taking a public stance of zero tolerance.

\section{Conclusions}

Those attending agreed that the Roundtable event had been a very useful forum for the exchange of views. It would also provide an effective basis for future collaboration. The British Library was commended for its leadership in organising the event. 
Four action points were agreed:

1. The meeting agreed that there would be benefit if the LIBER collection security network ${ }^{2}$ could be extended to include the major research libraries of North America, including those present. (A proposal, which also addressed the nature of the information to be shared via the network, was subsequently put to the LIBER Board in July 2008. The proposal was accepted.)

2. It was also agreed there would be value in developing a corpus of material from diverse sources on those found guilty of theft from research library collections. ${ }^{3}$ Conclusions about such individuals might be drawn from the evidence and areas for further research identified.

3. The meeting agreed there would be value in seeking to place newspaper articles to increase awareness and understanding of the importance of collection security for research libraries, the increasing vulnerability of collections and risk from theft, the significance of loss of heritage material from historic collections, and the need for deterrent sentencing. It was thought that high-profile scholars would be appropriate authors for such articles since in their words the messages might be more compelling.

4. It was further agreed that a questionnaire-based benchmarking exercise should be undertaken by the participants to assess the institutions' risk awareness/risk appetite over a range of issues relating to collection security. Participants considered that the benchmarking exercise might subsequently lead to the development of collection security guidelines.

\section{Notes}

${ }^{1}$ For example, the Victim Impact Statement submitted by the New York Public Library can be found at http://www.nypl.org/research/chss/map/ VictimImpactStatement082406.pdf.

${ }^{2}$ On 2 July 2002, the Executive Board of LIBER, in line with the Copenhagen Principles of 14 May 2002, endorsed the establishment of a Library Security Network to facilitate the exchange of confidential security information among European national, university and other important research libraries with valuable 
collections. The objective of the Network is to create a safe information and communication network, based on email, for European Library Directors and Security Managers. The Copenhagen Principles are available at http://www. libereurope.eu/node/163. See also article by Erland Kolding Nielsen http://liber. library.uu.nl/publish/articles/000236/article.pdf in this issue of LIBER Quarterly.

${ }^{3}$ A significant corpus of material on the Forbes Smiley thefts is brought together at http://www.maphistory.info/smileynews.html. See also Jesper Düring Jørgensen's account of the discovery of book thefts at the Royal Library, Copenhagen: Jørgensen, Jesper Düring: 'Report on a Theft of Books, a Non-fiction Detective Story', in: Care and Conservation of Manuscripts 9: Proceedings of the Ninth International Seminar Held at the University of Copenhagen 14th-15th April 2005. Copenhagen: Museum Tusculanum Press, 2005. See also article by Kowal and Rhatigan http:/ / liber.library. uu.nl/publish/articles/000247/article.pdf in this issue of LIBER Quarterly. 